\title{
Optimalizace odhodové vzdálenosti pro test přesnosti hodu na cíl u mládeže věkové kategorie 11-14 let
}

\section{Optimisation of a throwing distance to test throw accuracy of 11-14 year old children}

\author{
David Zahradník, František Vaverka
}

\author{
Ostravská univerzita, Ostrava
}

\begin{abstract}
Abstrakt:
Hod na přesnost nenív současné době ve školní tělesné výchově prúliš rozvíjen. Přesnost hodu je rozvijena pouze v rámci dovedností konkrétní sportovni discipliny. Tento nedostatek může vycházet $z$ absence vhodného testu diagnostikujícího tuto dovednost. V literatuře jsme se setkali pouze se třemi testy presnosti hodu vypracovanými pro školní mládež (Bös 2001; Mecner 1975; Měkota, Blahuš 1983). Testy se skládají z několika opakovaných sérií hodů, vủbec nediferencují odhodovou vzdálenost pro chlapce a dívky ani pro jednotlivé věkové skupiny a vyžadují poměrně složitý grafický záznam úspěšných zásahů terče, který nelze v hodině tělesné výchovy snadno a rychle vyhodnotit. Smyslem studie je vytvořit test prèesnosti hodu na cíl, který eliminuje uvedené nedostatky. Optimalizace odhodové vzdálenosti vychází z podmínky normálního rozdělení testových skóre u jednotlivých odhodových vzdáleností a z podmínky, že se průmèrný počet zásahů terče u konkrétní odhodové vzdálenosti bude bližit hodnotě 7,5 zásahů terče. K posouzení významnosti rozdílu sledovaných odhodových vzdálenosti byla použita jednofaktorová ANOVA. Zkoumaný soubor tvořilo 105 chlapců a 114 dívek tř́ náhodnè vybraných ostravských škol ve věku 11 až 14 let. Byly stanoveny tři odhodové vzdálenosti (chlapci $6 ; 8 ; 10 \mathrm{~m}$, dívky 3,5; 5,5; 7,5 m) v kombinaci s vertikálním kruhovým terčem o průmèru $0,7 \mathrm{~m}$. Testovaná osoba házela hodem nad úrovni ramene $z$ místa $z$ každé odhodové vzdálenosti 20 hodì. Skóre testu představoval počet zásahu terče z 6.-20. hodu (zácvik 1. -5. hod). Byly zjištěny optimální odhodové vzdálenosti pro test přesnosti hodu na cíl pro chlapce kategorie 11-12 let $(6 \mathrm{~m})$, kategorie 13-14 let (8 m), pro dívky kategorie 11-12 let (5,5 m), kategorie 13-14 let $(7,5 \mathrm{~m}) v$ kombinaci s terčem o průměru $0,7 \mathrm{~m}$.
\end{abstract}

\begin{abstract}
:
Throw accuracy is not being currently quite developed within school PE lessons; it is being developed only as part of skills of a particular sports discipline. This shortcoming may stem from the lack of a suitable test assessing this skill. In the literature we have seen only three throw accuracy tests intended for school youngsters (Bös 2001, Mecner 1975, Měkota; Blahuš 1983). These tests consist of a few repeated series of throws, failing to distinguish a throwing distance for boys and girls and even age groups, and requiring a rather complicated graphic record of successful target hits that cannot be assessed easily and quickly during a PE lesson. The purpose of the study is to create a test of measuring throw accuracy at a target eliminating the aforementioned shortcomings. The optimisation of a throwing distance is based on the condition of a normal Gaussian distribution of data related to individual throwing distances, and on the condition that an average number of target hits within a concrete throwing distance will be close to 7.5 target hits. To assess the importance of the difference of the observed throwing distances one-factor ANOVA (One Way Analysis of Variance) was used. The assessed group consisted of 105 boys and 114 girls of three randomly selected schools in Ostrava between 11 and 14 years old. Three throwing distances were determined (boys 6; 8; $10 \mathrm{~m}$, girls $3.5 ; 5.5 ; 7.5 \mathrm{~m}$ ) in combination with a vertical round target of $0.7 \mathrm{~m}$ in diameter. The tested person used an overarm throwing technique and made 20 throws for each throwing distance. The test score was the number of the target hits from the $6^{\text {th }}-20^{\text {th }}$ throw (training: $1^{\text {st }}-5^{\text {th }}$ throw). The optimum throwing distances were identified for the accuracy test of a target throw for boys of the 11-12 year category $(6 \mathrm{~m}), 13-14$ year category $(8 \mathrm{~m})$, for girls of the 11-12 year category $(5.5 \mathrm{~m}), 13-14$ year category $(7.5 \mathrm{~m})$ while using a target of $0.7 \mathrm{~m}$ in diameter.
\end{abstract}


Klíčová slova: Hod, přesnost, motorický test, mládež 11-14 let

Key words: $\quad$ Throw, accuracy, dexterity test, 11-14 year old children

\section{ÚVOD}

Jednu ze základních dovedností představuje v životě člověka hod nad úrovní ramene. V dávné historii představoval hod jeden $\mathrm{z}$ nutných prostředků využívaných $\mathrm{k}$ obživě a vlastní obraně. Jako projektily byly využíány kameny, později různé druhy oštěpů apod. Význam hodu na cíl v činnostech nutných pro obživu a obranu se začal vytrácet s postupným nástupem střelných zbraní. Oproti této zkušenosti začínal hod nabývat na významu v oblastech sloužících k zábavě, tj. různé druhy her, a ve sportu. V současné době se hod uplatňuje jako velmi důležitý prvek v celé řadě sportovních disciplín. Děti spontánně zvládnou jednoduchý hod nad úrovni ramene do dálky i na cíl v předškolním věku za pomoci dostupných projektilů jako jsou šišky, sněhové koule, kamínky apod. Přesnost hodu se zvyšuje s přibývajícím věkem a u stejně starých dětí nejsou rozdíly mezi pohlavími (Van Rossum, 1989). Ke stabilizaci základního hodu nad úrovní ramene dochází u dětí kolem sedmi let (Malina, 2004).

Existují dvě základní varianty házení a to hod na vzdálenost a na přesnost. Obě varianty hodů se uplatňují v celé řadě sportovních disciplín (házená, basketbal, baseball, softbal, atletika-oštěp, u dětí kriketový míček apod.). Analýzou hodu oštěpem se například zabýval (Sebera, 2008). V současné školní praxi se pěstuje pouze hod do dálky, jehož kvalita je posuzována dosaženou délkou hodu. Hod na cíl není v současné době ve školách rozvíjen. Hodu na cíl je věnována pozornost pouze v rámci konkrétních sportů, kde přesnost hodu je významnou dovedností. Př́činou chybějícího zaměření na přesnost hodu ve školní tělesné výchově může být absence vhodného testu diagnostikujícího tuto dovednost a vhodného a bezpečného projektilu.

Problémem přesnosti hodu se zabývala řada autorů (Miller, 2000; Edwards, 2007; Van Rossum, 1989; Dupuy, 2000; Terando, 2007). Úspěšný zásah terče vychází z optimální kombinace odhodového úhlu a rychlosti ve vztahu k odhodové vzdálenosti, velikosti terče a hmotnosti projektilu. Dovednost použití stabilizované techniky hodu je nutnou podmínkou úspěšného zásahu terče (Miller, 2000). Existuje velké množství možností různých kombinací odhodových parametrů vedoucích $\mathrm{k}$ zásahu cíle a je téměř vyloučeno dosáhnout ve dvou následných hodech jejich shodu (Hubbard, 2000). S rostoucí vzdáleností od terče narůstá počet chyb v úspěšnosti zásahu terče (Edwards, 2007). Dovednost přesnosti hodu má úzký vztah k problematice řízení pohybu a koordinaci oko-hlava-ruka (Schmidt a Lee, 2005). Zajímavou situaci může tvořit kombinace limitních odhodových parametrů. Házející subjekt může použít kombinaci vysoké odhodové rychlosti s malým odhodovým úhlem nebo nízkou odhodovou rychlost $s$ větším odhodovým úhlem. $\mathrm{V}$ obou př́ípadech dojde $\mathrm{k}$ úspěšnému zásahu terče za předpokladu jejich správné kombinace (Bartlett, 2000). Vztah mezi rychlostí a přesností je znám jako rychlostně-přesnostní kompromis (Schmidt a Lee, 2005). S narůstající rychlostí pohybu klesá přesnost a opačně (Fitts, 1954). Nižší odhodová rychlost a větší odhodový úhel vede k lepším výsledkům v testech přesnosti hodu na cíl. Barttlet (2000) informuje o existenci specifického odhodového úhlu směřujícího do středu terče a jemu odpovídající optimální odhodové rychlosti. Současně jsou uváděny meze odchylky jak pro rychlost tak pro úhel pro tuto dvojice hodnot, aby bylo dosaženo úspěšného zásahu terče. Meze odchylky mohou narůstat s rostoucí velikostí terče. Hod na přesnost ovlivňuje v čase řada vnějších faktorů, které nejsme schopni účinně kontrolovat. Proto je nutné diagnostikovat přesnost hodu $\mathrm{v}$ průběhu jedné série hodů, aby byl co nejvíce eliminován vliv vnějších faktorů. (Gajda, 2006) zjistil, že vzrůstající trend počtu úspěšných zásahů terče v testu přesnosti hodu na cíl se projevuje $\mathrm{v}$ sérii více hodů pouze mezi prvním a pátým hodem a v dalších pokusech se přesnost zásahů stabilizuje.

V literatuře jsou popsány testy využívající horizontálně orientovaný cíl (Miller a Bartlett 1992) nebo vertikálně orientovaný cíl (Bayios a Boudolos, 1998; Malina, 1968). Zásahy jsou hodnoceny bud' alternativně nebo jako odchylka od středu terče v oblasti vymezené soustřednými kruhy různých poloměrů (Malina, 1968; Mecner, 1975). Jiný přístup vychází z měření odchylek v horizontálním a vertikál- 
ním směru od středu terče (Malina, 1968; Mecner 1975; Měkota a Blahuš, 1983) nebo součtem bodů dosažených zásahem bodově různě hodnocených sektorů soupeřova hřiště (Měkota a Blahuš, 1983). Nejčastěji se vyskytují terče založené na principu soustředných kruhů. Testy přesnosti hodu zaměřené na diagnostiku základního hodu nad úrovní ramene se v literatuře vyskytují velmi zř́́dka (Malina, 1968; Bös, 2001; Mecner, 1975). Převážná většina testů není pro potřeby školní praxe vhodná, protože vychází z potřeby konkrétní sportovní disciplíny. Např. Watson uvádí softbal: (Malina, 1968), volejbal: (Měkota a Blahuš, 1983), basketbal: (Měkota a Blahuš, 1983), házená: (Bayios a Boudolos, 1998). V literatuře jsme se setkali pouze se třemi testy přesnosti hodu vypracovanými pro školní mládež (Bös, 2001; Mecner, 1975; Měkota a Blahuš, 1983). Všechny testy jsou př́liš složité pro rutinní užití v praxi. Každý z testů je založen na principu soustředných kruhů a vyžaduje poměrně složitý grafický záznam úspěšných zásahů terče, který nelze v hodině tělesné výchovy snadno a rychle vyhodnotit. Testy vůbec nediferencují odhodovou vzdálenost pro chlapce a dívky ani pro věkové skupiny. Testy se skládají z několika opakovaných sérií hodů. Autoři výše uvedených testů použili jako projektil standardní tenisový míč, který vyhovuje $\mathrm{z}$ hlediska bezpečnosti házejících osob.

(Zahradník a Vaverka, 2008) vytvořili test přesnosti hodu s cílem eliminovat výše uvedené nedostatky. Při konstrukci testu vycházeli autoři z níže uvedených požadavků na nový test. Požadavky byly formulovány s ohledem na každodenní rutinní použití ve školní praxi. Test přesnosti hodu na cíl musí splňovat: jednoduchou a jasnou detekci zásahů terče, absolvování procedury testování v rámci jedné série hodů, jednoduchý záznam testu, diferenciaci podmínek testu vzhledem pohlaví a věku, bezpečný a dostupný projektil. Test přesnosti hodu byl v první fázi vytvořen a následně ověřen na vzorku vysokoškolských studentů. Podstata testu přesnosti spočívala v hodu tenisovým míčem na vertikální kruhový terč. Zásah terče byl hodnocen dichotomicky (zásah-chyba). Házející subjekt si proto může sám kontrolovat úspěšnost házení a odpadá potřeba složitého grafického záznamu zásahů terče. Volba optimální kombinace odhodové vzdálenosti a velikosti terče pro soubor vysokoškolských studentů představovala základní princip konstrukce testu přesnosti hodu na cíl. Optimální kombinace odhodové vzdálenosti a velikosti terče musela splňovat dvě základní podmínky:

- Testové skóre tvořené počtem zásahů terče muselo vyhovovat podmínce normálního rozdělení u zkoumaného souboru.

- Průměr testových skóre zkoumaného souboru musel být blízký 5 zásahům terče (z 10 možných zásahů).

Pro experiment optimalizace bylo zvoleno devět kombinací odhodových vzdáleností a velikostí terče (odhodové vzdálenosti muži $6,10,14 \mathrm{~m}$, ženy $4,6,8 \mathrm{~m}$ ). Velikosti terče byly použity pro obě kategorie shodné $(0,3,0,7,0,9 \mathrm{~m})$. Výsledky ukázaly nejvhodnější odhodovou vzdálenost v kategorii mužů $10 \mathrm{~m}, \mathrm{v}$ kategorii žen $6 \mathrm{~m}$ v kombinaci $\mathrm{s}$ terčem o průměru $0,7 \mathrm{~m}$ pro zkoumaný soubor vysokoškolských studentů.

Předkládaná studie se zaměřuje na vytvoření testu přesnosti hodu na cíl, který by byl vhodný pro mládež ve věku 11-14 let. Východiskem k velikosti a poloze terče je postup prezentovaný ve studii (Zahradník a Vaverka, 2008). Jako nejvhodnější terč se ukázal u vysokoškolských studentů v kategorii mužů i žen kruhový terč o průměru $0,7 \mathrm{~m}$. V této studii se budeme zabývat pouze stanovením optimální vzdálenosti pro test přesnosti hodu na cíl při velikosti terče o průměru $0,7 \mathrm{~m}$. Odhodové vzdálenosti v kombinaci se stabilní velikostí terče musí splňovat stejné podmínky formulované výše. Průměr testových skórů zkoumaného souboru mládeže 11-14 let musí být blízký 7,5 zásahům terče a směrodatná odchylka přibližně 2,5 zásahů terče (z 15 možných zásahů terče). Za věcně významný rozdíl mezi průměry testových skóre zkoumaných odhodových vzdálenosti budeme považovat 2,5 zásahů terče.

\section{METODIKA}

Zkoumaný soubor tvořilo 105 chlapců a 114 dívek ve věku 11-14 let tří náhodně vybraných ostravských škol ve věku 11 až 14 let. Do souboru byli zařazeni žáci, kteří neměli zásadní nedostatky v technice základního hodu nad úrovní ramene. Základní charakteristiky chlapců a dívek jsou uvedeny v tabulce 1 . 
Tabulka 1 Základní charakteristiky vyšetřovaného souboru $(\bar{X} \pm S)$

\begin{tabular}{|c|c|c|c|c|c|c|c|c|}
\hline \multirow{2}{*}{$\begin{array}{c}\text { Věk } \\
(\text { roky })\end{array}$} & \multicolumn{4}{|c|}{ Chlapci } & \multicolumn{4}{c|}{ Dívky } \\
\cline { 2 - 9 } & $\mathbf{n}$ & $\begin{array}{c}\text { Věk } \\
(\text { roky) }\end{array}$ & $\begin{array}{c}\text { Hmot. } \\
(\mathbf{k g})\end{array}$ & $\begin{array}{c}\text { Výška } \\
(\mathbf{c m})\end{array}$ & $\mathbf{n}$ & $\begin{array}{c}\text { Věk } \\
(\text { roky) }\end{array}$ & $\begin{array}{c}\text { Hmot. } \\
(\mathbf{k g})\end{array}$ & $\begin{array}{c}\text { Výška } \\
(\mathbf{c m})\end{array}$ \\
\hline $\mathbf{1 1}$ & 29 & $11,4 \pm 0,5$ & $46,7 \pm 7,8$ & $154 \pm 7,8$ & 34 & $11,2 \pm 0,4$ & $42,4 \pm 7,3$ & $155 \pm 6,9$ \\
\hline $\mathbf{1 2}$ & 33 & $12,6 \pm 0,6$ & $50,3 \pm 11,2$ & $159 \pm 4,0$ & 31 & $12,4 \pm 0,4$ & $50,6 \pm 7,5$ & $160 \pm 7,1$ \\
\hline $\mathbf{1 3}$ & 27 & $13,5 \pm 0,5$ & $62,1 \pm 12,5$ & $170 \pm 6,7$ & 30 & $13,4 \pm 0,5$ & $53 \pm 6,6$ & $165 \pm 3,2$ \\
\hline $\mathbf{1 4}$ & 15 & $14,4 \pm 0,5$ & $70 \pm 10,5$ & $180 \pm 6,6$ & 19 & $14,3 \pm 0,5$ & $52,3 \pm 5,7$ & $166 \pm 5,6$ \\
\hline
\end{tabular}

Výsledný test se skládá z 20 bezprostředně po sobě jdoucích hodů, kde 1.-5. hod představuje zácvik. Skóre testu poté představuje počet zásahů terče 6 . až 20. hodu. Podmínky testu budou optimálně nastaveny pro každou věkovou kategorii chlapců a dívek změnou odhodové vzdálenosti. Jednotlivé varianty testu prezentuje Obr.1. Testované osoby byly před zahájením testování řádně poučeny a motivovány k maximálnímu soustředění a k co nejlepšímu výsledku. Poté následovalo rozcvičení.

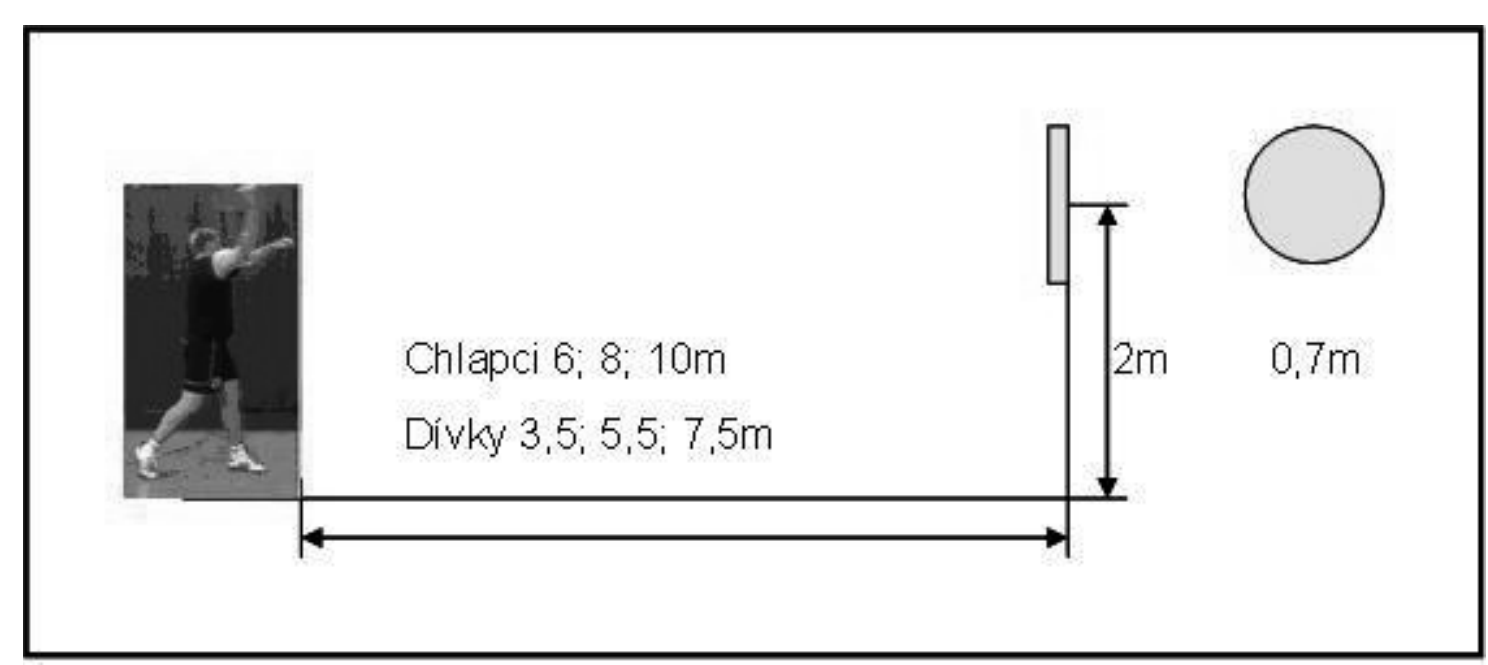

Obr. 1 Jednotlivé varianty testu přesnosti hodu na cíl

Testovaná osoba hází ve stoji tenisovým míčem z vyznačeného odhodového místa preferovanou paží hodem nad úrovní ramene na vertikální kruhový terč. Po celou dobu hodu jsou obě nohy v kontaktu s podložkou. Testované osoby prováděly na každé ze tř́i kombinací velikosti terče a odhodové vzdálenosti 20 hodů. Každá TO provedla ve třech kombinacích vzdálenosti a velikosti terče celkem 60 hodů. K eliminaci zácviku u testovaných osob byla použita metoda latinského čtverce. Testované osoby byly rozděleny do trojic. Každá trojice testovaných osob začínala házet $\mathrm{z}$ jiné odhodové vzdálenosti. Průměrný čas nutný pro jednu odhodovou vzdálenost byl dodržován průměrně kolem 4,5 min. Poté následoval odpočinek minimálně 3 minuty, předtím než trojice postoupila k jiné odhodové vzdálenosti.

Pro řešení studie jsme použili níže uvedené statistické postupy. Popis normálního rozdělení testových skóre ve všech sledovaných prrípadech zajištují aritmetický průměr a směrodatná odchylka a k ověření jeho normality byl použit test Shapiro-Wilk. K posouzení významnosti rozdílu sledovaných variant odhodových vzdálenosti byla použita jednofaktorová ANOVA, požadavek homogenity rozptylů byl ověřen Leveneho testem a post hoc testem Scheffeho. K analýze získaných dat byl použit statistický produkt SPSS 18.0. 


\section{VÝSLEDKY}

Základní popisné charakteristiky v kategorii chlapců a dívek popisuje tabulka 2.

Tabulka 2 Popisná statistika kategorie chlapci, dívky

\begin{tabular}{|c|c|c|c|c|c|c|c|c|c|c|c|c|c|c|}
\hline \multirow{4}{*}{$\begin{array}{c}\text { Věk } \\
\text { (roky) }\end{array}$} & \multicolumn{7}{|c|}{ Chlapci } & \multicolumn{7}{|c|}{ Dívky } \\
\hline & \multicolumn{7}{|c|}{ Odhodová vzdálenost (m) } & \multicolumn{7}{|c|}{ Odhodová vzdálenost (m) } \\
\hline & \multirow[b]{2}{*}{$\mathrm{n}$} & \multicolumn{2}{|c|}{6} & \multicolumn{2}{|c|}{8} & \multicolumn{2}{|c|}{10} & \multirow[b]{2}{*}{$\mathrm{n}$} & \multicolumn{2}{|c|}{3,5} & \multicolumn{2}{|c|}{5,5} & \multicolumn{2}{|c|}{7,5} \\
\hline & & $\bar{x}$ & $\mathrm{~s}$ & $\bar{x}$ & $\mathrm{~s}$ & $\bar{x}$ & $s$ & & $\bar{X}$ & $\mathrm{~s}$ & $\bar{x}$ & $\mathrm{~s}$ & $\bar{x}$ & $\mathbf{s}$ \\
\hline 11 & 29 & 7,2 & 3,2 & 5,3 & 2,3 & 3,2 & 2,3 & 34 & 11,1 & 2,9 & 6,5 & 2,4 & 3,9 & 2,2 \\
\hline 12 & 33 & 8,2 & 2,6 & 5,7 & 2,7 & 3,8 & 2 & 31 & 12,5 & 2,3 & 8,1 & 2,6 & 4,5 & 2,4 \\
\hline 13 & 27 & 9,6 & 3,2 & 6,1 & 2,7 & 4,7 & 2,4 & 30 & 12,5 & 1,7 & 9,3 & 2,8 & 5,8 & 2,9 \\
\hline 14 & 15 & 10,8 & 1,8 & 8,5 & 1,9 & 5,2 & 2,7 & 19 & 13,1 & 1,4 & 9,8 & 2,2 & 6,7 & 2,1 \\
\hline
\end{tabular}

U všech tří odhodových vzdáleností dochází k postupnému nárůstu průměrného počtu zásahů terče v závislosti na věku chlapců. U odhodové vzdálenosti $6 \mathrm{~m}$ dosahují průměrné počty zásahů terče hodnot od 7,2 u kategorie 11 let, do 10,8 u kategorie 14 let. U odhodových vzdáleností $8 \mathrm{~m}$ a $10 \mathrm{~m}$ je trend podobný. Směrodatné odchylky se pohybují ve všech odhodových vzdálenostech u všech ročníků v intervalu od 1,8 do 3,2.

Podobných výsledků bylo dosaženo v kategorii dívek. Trend postupného nárůstu počtu úspěšných zásahů terče v závislosti na věku se projevil u všech odhodových kombinací. Pouze u kategorie 12 a 13 let u odhodové kombinace $3,5 \mathrm{~m}$ bylo dosaženo shodných hodnot průměrného počtu úspěšných zásahů terče. Směrodatné odchylky se pohybují ve všech odhodových vzdálenostech u všech kategorií v intervalu od 1,4 do 2,9.

Výsledky ověřování normality rozdělení testových skórů u všech sledovaných variant prezentuje tabulka 3.

Tabulka 3 Normalita rozložení experimentálních dat (Shapiro-Wilk)

\begin{tabular}{|c|c|c|c|c|c|c|}
\hline \multirow{2}{*}{ Věk (roky) } & \multicolumn{3}{|c|}{ dívky } & \multicolumn{3}{c|}{ chlapci } \\
\cline { 2 - 7 } & \multicolumn{3}{|c|}{ odhodová vzdálenost (m) } & \multicolumn{3}{c|}{ odhodová vzdálenost (m) } \\
\cline { 2 - 7 } & $\mathbf{3 , 5}$ & $\mathbf{5 , 5}$ & $\mathbf{7 , 5}$ & $\mathbf{6}$ & $\mathbf{8}$ & $\mathbf{1 0}$ \\
\hline $\mathbf{1 1}$ & $0,28^{\star}$ & $0,38^{\star}$ & $0,61^{\star}$ & $0,06^{\star}$ & $0,51^{\star}$ & $0,49^{\star}$ \\
\hline $\mathbf{1 2}$ & 0,00 & $0,69^{\star}$ & $0,28^{\star}$ & $0,06^{\star}$ & $0,06^{\star}$ & 0,04 \\
\hline $\mathbf{1 3}$ & $0,15^{\star}$ & $0,61^{\star}$ & $0,17^{\star}$ & $0,31^{\star}$ & $0,22^{\star}$ & $0,38^{\star}$ \\
\hline $\mathbf{1 4}$ & 0,03 & 0,03 & $0,21^{\star}$ & $0,25^{\star}$ & $0,25^{\star}$ & 0,02 \\
\hline
\end{tabular}

*normální rozdělení

U chlapců byla normalita potvrzena ve všech případech s výjimkou odhodové vzdálenosti $10 \mathrm{~m}$ u kategorie 12 a 14 let. U dívek byla normalita rovněž potvrzena ve všech případech s výjimkou odhodové vzdálenosti 3,5 m u kategorie 12 let, 14 let a u odhodové vzdálenosti 5,5 m u kategorie 14 let.

Optimální odhodové vzdálenosti v kategorii chlapců i děvčat prezentuje Tabulka 4.

Tabulka 4 Průměrný počet úspěšných zásahů terče

\begin{tabular}{|c|c|c|c|c|c|c|c|c|c|}
\hline \multirow{2}{*}{ odh.vzd. } & \multicolumn{4}{|c|}{ dívky věk (roky) } & \multirow{2}{*}{ odh.vzd. } & \multicolumn{4}{|c|}{ chlapci věk (roky) } \\
\cline { 2 - 8 } & 11 & 12 & 13 & 14 & & 11 & 12 & 13 & 14 \\
\hline 3,5 & 11,1 & 12,5 & 12,5 & 13,1 & $\mathbf{6}$ & $\mathbf{7 , 2 ^ { \star }}$ & $\mathbf{8 , 2 ^ { * }}$ & 9,6 & 10,8 \\
\hline $\mathbf{5 , 5}$ & $\mathbf{6 , 5}^{\star}$ & $\mathbf{8 , 1 ^ { \star }}$ & 9,3 & 9,8 & $\mathbf{8}$ & 5,3 & 5,7 & $\mathbf{6 , 1}^{\star}$ & $\mathbf{8 , 5}^{\star}$ \\
\hline $\mathbf{7 , 5}$ & 3,9 & 4,5 & $\mathbf{5 , 8 ^ { \star }}$ & $\mathbf{6 , 7}$ & $\mathbf{1 0}$ & 3,2 & 3,8 & 4,7 & 5,2 \\
\hline
\end{tabular}

*nejvhodnější odhodová vzdálenost pro danou kategorii - blízká 7,5 zásahům terče 
Podmínce dosažení průměrného počtu úspěšných zásahů terče se nejvíce blíží v kategorii chlapců 11 let odhodová vzdálenost $6 \mathrm{~m}(7,2), 12$ let $6 \mathrm{~m}(8,2), 13$ let $8 \mathrm{~m}(6,1)$ a 14 let $8 \mathrm{~m}(8,5)$. V kategorii dívek se nejvíce blíží podmínce průměrného počtu úspěšných zásahů terče odhodová vzdálenost 11 let $5,5 \mathrm{~m}(6,5), 12$ let $5,5 \mathrm{~m}(8,1), 13$ let 7,5 m (5,8), 14 let 7,5 m (6,7). Výsledky ukazují, že pro kategorie 11-12 let u chlapců vyhovuje odhodová vzdálenost $6 \mathrm{~m}$ a děvčat 11-12 let $5,5 \mathrm{~m}$. Stejná situace nastala v kategorii chlapců $13-14$ let kde se ukazuje nejvhodnější odhodová vzdálenost $8 \mathrm{~m}$ a u dívek 13-14 let odhodová vzdálenost 7,5 $\mathrm{m}$.

Všechny tři odhodové vzdálenosti byly u všech ročníků chlapců a děvčat podrobeny Leveneho testu homogenity rozptylů. Výsledky testu potvrdily, že nelze zamítnout nulovou hypotézu o rovnosti rozptylů. Vzhledem k těmto výsledkům jsme použili jednofaktorovou analýzu rozptylu a následně Post Hoc Test (Scheffe). Analýzou byly zjištěny statisticky významné rozdíly mezi průměry počtů úspěšných zásahů terče pro jednotlivé ročníky chlapců a dívek. Post Hoc Test rozdělil odhodové vzdálenosti do tří homogenních skupin u všech ročníků chlapců a děvčat. Jako příklad za všechny zde uvádíme v Tabulce 5 výsledky kategorie 12 let u dívek.

Tabulka 5 Post Hoc Test dívky 12 let

\begin{tabular}{|c|c|c|c|}
\hline \multirow{2}{*}{$\begin{array}{c}\text { odhod. } \\
\text { vzdálenost } \\
(\mathbf{m})\end{array}$} & $\mathbf{3}$ & $\mathbf{2}$ & $\mathbf{3}$ \\
\cline { 2 - 4 } & 4,5 & & \\
\hline 7,5 & & $8,1^{\star}$ & \\
\hline 5,5 & & & 12,5 \\
\hline 3,5 & & & \\
\hline
\end{tabular}

* nejvhodnější odhodová vzdálenost

Výsledky jednofaktorové analýzy jednoznačně rozdělily průměrné počty úspěšných zásahů terče do tří homogenních skupin. Průměrné počty zásahů terče se u jednotlivých odhodových kombinací vzájemně nepřekrývají. Tato skutečnost potvrzuje, že jednotlivé odhodové vzdálenosti nejsou vzájemně zastupitelné pro diagnostiku dovednosti přesnosti hodu. Pro test přesnosti hodu na cíl budou použity v kategorii 11-12 let odhodové vzdálenosti $6 \mathrm{~m}$ u chlapců a u dívek 5,5 $\mathrm{m}$. V kategorii 13-14 let budou použity odhodové vzdálenosti u chlapců $8 \mathrm{~m}$ a u dívek $7,5 \mathrm{~m}$ v kombinaci s terčem o průměru $0,7 \mathrm{~m}$.

\section{DISKUSE}

V současné době dostupné motorické testy postihující dovednost přesnosti hodu na cíl vycházejí z potřeb konkrétní sportovní disciplíny (Bayios a Boudolos, 1998; Malina, 1968; Miller a Bartlett, 1992). Nespecifické testy přesnosti určené pro školní mládež prezentují (Bös, 2001; Mecner, 1975; Měkota a Blahuš, 1983). Není zřejmé, jakým způsobem autoři výše uvedených testů došli k použité kombinaci odhodové vzdálenosti a velikosti terče. Předložená studie vychází z práce (Zahradník a Vaverka, 2008), kde byla prezentována metodika pro stanovení optimální kombinace velikosti terče a odhodové vzdálenosti ověřená na vzorku vysokoškolských studentů.

Optimalizace velikosti terče a odhodové vzdálenosti spočívala v nalezení takové kombinace velikosti terče a vzdálenosti, která by vyhovovala výše uvedeným podmínkám, kdy zkoumaný soubor dosáhne průměrného počtu úspěšných zásahů terče ze všech hodů a současně výsledné skóre bude vyhovovat podmínce normálního rozdělení. Použitý terč o průměru $0,7 \mathrm{~m}$ vycházel jako nejvhodnější vzhledem $\mathrm{k}$ použitému projektilu (tenisový míč). Stejná velikost terče byla použita v pilotní studii jejíž cílem bylo navrhnout vhodné odhodové vzdálenosti pro jednotlivé ročníky základní školy (není součásti studie).

$\mathrm{Na}$ základě výsledků pilotního experimentu byly zvoleny pro každou kategorii tři odhodové vzdálenosti, které byly použity ve všech ročnících druhého stupně základní školy.

K stabilizaci techniky hodu nad úrovní ramene dochází u dětí kolem sedmi let (Malina, 2004). Přesnost hodu se zvyšuje s přibývajícím věkem (Van Rossum, 1989). Podobných výsledků bylo dosaženo v naší studii. U každé odhodové vzdálenosti docházelo v závislosti na zvyšujícím se ročníku k nárůstu prů- 
měrného počtu úspěšných zásahů terče. Tato skutečnost byla potvrzena u obou kategorií chlapců a dívek. Jediné výjimky bylo dosaženo v kategorii dívek u odhodové vzdálenosti $3,5 \mathrm{~m}$, stejného průměrného počtu úspěšných zásahů terče u dívek kategorie 13 a 14 let. Rozdíly mezi jednotlivými ročníky mohou být způsobeny rozdílnou vyzrálostí dovednosti přesnosti hodu. Tato skutečnost je v souladu s uvedenými autory.

I přes uvedené rozdíly $\mathrm{v}$ průměrném počtu úspěšných zásahů terče se ukazuje jako nejvhodnější odhodová vzdálenost v kategorii chlapců 11-12 let 6m a v kategorii 13-14 let odhodová vzdálenost $8 \mathrm{~m}$. Vzhledem $\mathrm{k}$ malému počtu chlapců kategorie 14 let bude nutno tuto skutečnost ověrit na rozsáhlejším vzorku školních dětí. V kategorii dívek se ukazuje být nejvhodnější odhodovou vzdáleností 5,5 $\mathrm{m}$ v kategorii 11-12 let a odhodová vzdálenost 7,5 m v kategorii 13-14 let. Výhodu jednotné odhodové vzdálenosti pro několik ročníku vidíme v možnosti sledování dynamiky vývoje dovednosti přesnosti hodu.

\section{ZÁVĚRY}

Optimalizace odhodové vzdálenosti pro test přesnosti hodu na cíl pro chlapce a dívky věkové kategorie 11-14 let druhého stupně základní školy je podmíněna splněním dvou výše uvedených podmínek:

Výzkum prokázal, že k průměrné hodnotě 7,5 úspěšných zásahů terče se bliží u chlapců odhodová vzdálenost $6 \mathrm{~m}$ pro kategorii 11-12 let a odhodová vzdálenost $8 \mathrm{~m}$ pro kategorii 13-14 let.

Výzkum prokázal, že k průměrné hodnotě 7,5 úspěšných zásahů terče se blíží u dívek odhodová vzdálenost 5,5 m pro kategorie 11-12 let a odhodová vzdálenost 7,5 m pro kategorii 13-14 let.

Výzkum prokázal, že podmínku normality rozložení experimentálních dat splňuje u obou kategorií většina zkoumaných odhodových vzdáleností s výjimkou odhodové vzdálenosti $10 \mathrm{~m}$ u kategorie 12 a 14 let u chlapců a odhodová vzdálenost $3,5 \mathrm{~m}$ u kategorie 12 let a odhodová vzdálenost $5,5 \mathrm{~m}$ u kategorie 14 let u dívek.

Při splnění stanovených podmínek navrhujeme pro test přesnost hodu na cíl u dětí druhého stupně základní školy výše uvedené odhodové vzdálenosti v kombinaci s terčem $0,7 \mathrm{~m}$.

\section{Literatura}

BARTLETT, R. Principles of Throwing. In Biomechanics in Sport. Oxford: Blackwell Science, 2000, s. 365-380. ISBN 978-0-7360-6338-8.

BAYIOS, I., BOUDOLOS, K. Accuracy and throwing velocity in handball. In XVI International Symposium on Biomechnics in Sports. Konstanz: Universitätsverlag Konstanz, 1998, s. 55-58. ISSN 1999-4168.

BÖS, K. Handbuch Motorische Tests. Göttingen: Hogrefe, 2001. ISBN 3-8017-0411-4.

DUPUY, M.A.; MOTTET, D.; RIPOLL, H. The regulation of release parameters in underarm precision throwing. Journal of Sports Science, 2000, roč. 18, č. 6, s. 375-382. ISSN 02640414.

EDWARDS, B.; WATERHOUSE, J.; ATKINSON, G.; REILLY, T. Effects of time of day and distance upon accuracy and consistency of throwing darts. Journal of Sports Sciences, 2007, roč. 25, č. 13, s.1531-1538. ISSN 02640414

FITTS, P. M. The information capacity of the human motor system in controlling the amplitude of movement. Journal of Experimental Psychology, 1954, 47, s. 381-391. ISSN 0022-1015.

GAJDA, V. Reliabilita motorických testů a model měření. In Diagnostika motoriky mládeže. Ostrava: Repronis, 2006, s. 43-46.

HUBBARD, M. The Flight of Sports Projectiles. In Biomechanics in Sport.. Oxford: Blackwell Science, 2000, s. 381-400. ISBN 978-0-7360-6338-8.

MALINA, M.R.; BOUCHARD, C.; BAR-OR, O. Growth, Maturation, and Physical Activity. Champaign, IL: Human Kinetics, 2004. ISBN 0-88011-882-2.

MALINA, M. R. Reliability of different methods of scoring throwing accuracy. The Research Quaterly, 1968, 39, s.149-160. 
MECNER, J. Příspěvek k hodnocení spolehlivosti testu házení na cíl. Teorie a praxe tělesné výchovy, 1975, 23, s. 727-733. ISSN 0040358X

MĚKOTA, K.; BLAHUŠ, P. Motorické testy v tělesné výchově. Praha: SPN, 1983.

MILLER, S. Variability in basketball shooting: Practical implications. In Proceedings of XVII International Symposium on Biomechanics in Sports. Hong Kong: Department of Science and Physical Education, The Chinese University of Hong Kong, 2000, s. 887-894. ISSN 1999-4168.

MILLER, S.; BARTLETT, R. The effects of increased distance on basketball shooting kinematics. In Proceedings of the tenth ISBS Symposium. Milano: Edi. Ermes, 1992, s. 44-47. ISSN 1999-4168.

SEBERA, M.; NOVOTNÝ, M.; ZVONAŘ, M.; BERÁNKOVÁ, L. Biomechanická 3D analýza hodu oštěpem. Studia sportiva, Brno: FSpS MU, 2008, 2, s. 27-40. ISSN 1802-7679. SCHMIDT, R. A.; LEE, D. L. Motor control and learning: a behavioral emphasis. Champaign, IL: Sheridan Books, 2005. ISBN 0-7360-4258-X.

TERANDO, M.; RANGANATHAN, R.; CARLTON, L.G. Projektile motion: The effects of relative release height and target distance on release parameters. Journal of Sport \& Exercise Psychology, 2007, 29, s. 135-136. ISSN 08952779.

VAN ROSSUM, J.H.A.; BOOTSMA, R.J. The underarm throw for accuracy in children. Journal of Sports Sciences, 1989, roč. 7, č. 2, s. 101-112. ISSN 026404041.

ZAHRADNÍK, D.; VAVERKA, F.; GAJDA, V. Optimization of the size of a target and the throwing distance during a throw at a target for adults. Acta Universitatis Palackianae Olomucensis, 2008, roč. 38, č. 4, s. 39-47. ISSN 1212-1185. 